\title{
Association Between Weekend and Holiday Admission with Pneumonia and Mortality in a Tertiary Center in Portugal: A Cross-Sectional Study
}

\author{
Associação Entre os Internamentos ao Fim-De-Semana \\ e Feriados por Pneumonia e a Mortalidade num Centro \\ Terciário em Portugal: Um Estudo Transversal
}

\author{
Margarida Barreto CORTES* $\square^{1}$, Samuel Raimundo FERNANDES ${ }^{* 2}$, Patrícia ARANHA ${ }^{* 1}$, Luís Brito AVÔ*1, \\ Luís Menezes FALCÃO*1
}

Acta Med Port 2017 May;30(5):361-367 - https://doi.org/10.20344/amp.8029

\section{ABSTRACT}

Introduction: Acute bacterial pneumonia is a common and potentially fatal disease where early recognition and treatment are crucial. Increasing medical literature suggests worse outcomes in patients admitted for medical and surgical conditions during the weekend. Little is known about this effect in patients with acute bacterial pneumonia.

Objective: The aim of this study was to evaluate the impact of weekend and holiday hospital admission on the outcomes of acute bacterial pneumonia.

Material and Methods: Retrospective analysis of adult patients ( $>18$ years) with acute bacterial pneumonia collected from a tertiary referral center database. Length of stay, total cost, admission to intensive care unit, development of sepsis and organ failure, and mortality were compared between patients admitted on a weekday and patients admitted during a weekend or holiday.

Results: We analyzed 53854 hospital admissions from 42512 patients (median age 84.0 years, range 18 - 118 years), corresponding to 30554 admissions during weekdays, 21222 at weekends and 2078 during public holidays. Weekend and holiday admission was not associated with increased costs, length of stay, intensive care unit admission, development of sepsis, organ failure, and mortality. Conclusion: A weekend/holiday effect in acute bacterial pneumonia was not evident in our series.

Keywords: Holidays; Hospital Mortality; Hospitalization/statistics \& numerical data; Patient Admission/statistics \& numerical data Pneumonia; Portugal; Time Factors

\section{RESUMO}

Introdução: A pneumonia aguda bacteriana é uma entidade comum e potencialmente fatal em que o diagnóstico e tratamento precoces são cruciais. A literatura médica, de forma crescente, reporta piores resultados clínicos em doentes admitidos por doenças médicas e cirúrgicas durante o fim-de-semana. Pouco se sabe deste efeito em doentes com pneumonia aguda bacteriana.

Objetivo: O objetivo deste estudo foi avaliar o impacto das admissões durante o fim-de-semana e feriados nos resultados clínicos de doentes admitidos com pneumonia aguda.

Material e Métodos: Análise retrospetiva de doentes adultos (>18 anos) com pneumonia aguda bacteriana recolhidos de uma base de dados de um centro hospitalar terciário. A duração do internamento, custos, admissão em unidade de cuidados intensivos, desenvolvimento de sépsis ou lesão de órgão alvo e mortalidade foram comparados entre doentes admitidos durante a semana e doentes admitidos durante o fim-de-semana ou feriados.

Resultados: Verificaram-se 53854 admissões hospitalares correspondendo a 42512 doentes (idade mediana 84,0 anos, 18 - 118 anos). Um total de 30554 admissões ocorreram durante os dias da semana, 21222 durante o fim-de-semana e 2078 durante feriados. A admissão durante o fim-de-semana ou feriado não se associou a custos mais elevados, internamentos mais prolongados, maior admissão em unidade de cuidados intensivos, desenvolvimento de sépsis ou lesão de órgão alvo e mortalidade.

Conclusão: A hipótese dos internamentos durante o fim-de-semana e feriados se associarem a piores resultados clínicos não se verificou no nosso estudo.

Palavras-chave: Admissão do Doente/estatística \& dados numéricos; Factores de Tempo; Férias; Hospitalização/estatística \& dados numéricos; Mortalidade Hospitalar; Periodicidade; Pneumonia; Portugal

\section{INTRODUCTION}

Countries in developed regions of the world are experiencing an ageing of their population, a trend that is expected to continue in the coming years. The result is a demand for the health care system greater than ever before, with more and more patients being admitted to the hospital each year. It is a known fact that in most centers outside standard working hours, and particularly at weekends and holidays, the levels of medical, nursing and auxiliary staffing are substantially lower. ${ }^{1}$ Evidence is accumulating to suggest that patients admitted during the weekend and holidays are at higher risk for complications and mortality compared with patients admitted during the weekdays. This effect has been demonstrated in several conditions including acute coronary syndrome, congestive heart failure, acute subarachnoid hemorrhage, stroke, upper gastrointestinal bleeding, acute exacerbation of

*Author contributions: All authors contributed equally to the elaboration of the manuscript.

1. Departamento de Medicina Interna. Hospital de Santa Maria. Centro Hospitalar Lisboa Norte. Lisboa. Portugal.

2. Departamento de Gastroenterologia e Hepatologia. Hospital de Santa Maria. Centro Hospitalar Lisboa Norte. Lisboa. Portugal.

$\square$ Autor correspondente: Margarida Barreto Cortes. margaridabarretocortes@msn.com

Recebido: 07 de outubro de 2016 - Aceite: 03 de fevereiro de 2017 | Copyright @ Ordem dos Médicos 2017 
chronic obstructive pulmonary disease and cellulites. ${ }^{2-5}$ Recognition of this important effect may bring changes that can potentially improve patient clinical management and outcomes. In countries like Portugal, primary health care resources are closed during national holidays and weekends. Consequently, care for these patients may be hampered during these periods. Acute pneumonia, an inflammation of the lung parenchyma, is a potentially serious medical condition, especially in young children and elderly patients. Patients with pneumonia need urgent treatment. A rapid diagnosis and treatment are important to reduce infection-driven systemic inflammatory activation and multiorgan dysfunction. ${ }^{6}$ It is therefore not unexpected that a delay in appropriate management can result in increased mortality. ${ }^{7,8}$ Studies exploring the existence of a weekend effect in acute pneumonia have shown mixed results. ${ }^{9-13}$

In this study, we sought to evaluate the impact of weekend and holiday admissions on the outcomes of acute bacterial pneumonia using a large cohort of patients from a major tertiary center. To our knowledge, this will be the first study evaluating the weekend effect in Portuguese patients with acute pneumonia.

\section{MATERIAL AND METHODS}

\section{Study design and patients}

This was a retrospective analysis of an in-patient database from a large tertiary center in Portugal (Santa Maria Hospital). Clinical information was collected from admissions between June/1989 and December/2015. The primary endpoint was in-hospital mortality of any cause in patients with acute bacterial pneumonia, and the secondary endpoints included development of sepsis, organ failure, admission to the intensive care unit (ICU), length of stay and total costs calculated in euros $(€)$. Data was retrieved using the Classification of Diseases and Related Health Problems $9^{\text {th }}$ Revision (ICD-9) codes. Only adult patients (> 18 yearsold) with a primary diagnosis of bacterial pneumonia were included. Weekend admission was defined as a hospital admission between 16:00 hours on Friday to 23:59 hours on Sunday. For correctly assessing the effect of understaffing, holiday admissions were also included in the weekend admission group.

\section{Definition of organ failure and sepsis}

Specific organ failures and sepsis were defined using respective ICD-9 codes (Appendix 1) [http://www. actamedicaportuguesa.com/revista/index.php/amp/article/ view/8029/5040]. Each organ failure was dichotomized as present or absent within each admission. This definition has been used in other similar studies estimating the weekend effect. ${ }^{14,15}$

\section{Estimation of costs}

Estimation of the costs of hospital admissions was based on the national pricing table published by the Portuguese Ministry of Health system.

\section{Statistical analysis}

We used a Kolmogorov-Smirnov test to evaluate normal distribution of continuous variables. Continuous variables were expressed in mean \pm standard deviation (SD) or median + range depending on normal or non-normal distribution. Normal distribution continuous variables were compared using $t$-Student independent samples test and Mann-Whitney test for continuous variables with nonnormal distribution. Categorical variables were described using frequencies and percentages and chi-square contingency tables were used to compare proportions between groups. The association between each day of the week and in-hospital mortality was evaluated, with adjustment for the same array of potential risk factors. Odd ratios and $95 \%$ confidence intervals $(\mathrm{Cl})$ were determined. Similarly, multiple linear and logistic regression analyses were performed to evaluate the impact of weekend/holiday admission on mortality, ICU admission and total costs with adjustment for potential confounders. Length of stay and total costs were logarithmically transformed because of their skewed distributions. Significance level was chosen at 0.05. Statistical analysis was performed using SPSS v21.0.

\section{RESULTS}

Characteristics of patients with weekend and weekday admission

During the three decades (1989 - 2015) included in the study, 42512 adult patients were admitted with the primary diagnosis of acute bacterial pneumonia corresponding to a total of 53876 admissions. Fifty-five percent of patients were male with median age of 84.0 years (range 18 - 118). Thirty thousand five-hundred fifty-four patients $(56.7 \%)$ were admitted on weekdays, 21222 (39.4\%) on weekends, and 2078 (3.9\%) during public holidays. The patients' characteristics and clinical outcomes are summarized in Table 1.

The median age of patients admitted during the weekend/holidays was slightly higher than that of patients admitted during the weekdays - 84.0 years $(18$ - 118) vs 85.0 years $(18-118), p<0.001)$. This difference was mainly accounted by patients over 75 years of age $(p=0.006)$. There were no differences in gender over all age stratus

Table 1 - Patient demographics, disease characteristics and clinical outcomes

\begin{tabular}{lc}
\hline Sample size ( $\mathbf{n})$ & 53876 \\
Male gender, $\mathbf{n}(\%)$ & $29408(54.6)$ \\
Age in years, median (IQR) & $84.0(18-118)$ \\
Day of admission, $\mathbf{n}(\%)$ & \\
Weekdays & $30554(56.7)$ \\
Weekend & $21222(39.4)$ \\
Holidays & $2078(3.9)$ \\
Complications, $\mathbf{n}(\%)$ & \\
Sepsis & $2984(5.5)$ \\
Cardiovascular failure & $1819(3.4)$ \\
Respiratory failure & $1354(2.5)$ \\
Liver failure & $593(1.1)$ \\
Renal failure & $1831(3.4)$ \\
Outcomes & \\
Mortality, $n$ (\%) & $10440(19.4)$ \\
ICU admission, $\mathrm{n}(\%)$ & $3171(5.9)$ \\
Hospital stay in days, median (IQR) & $9.0(0-866)$ \\
Total costs in euros, median (IQR) & $5431(1358-393318)$ \\
\hline ICU: Intensive care unit; IQR: Interquartile range &
\end{tabular}


$(p=0.422)$.

\section{Trends of hospitalization over time}

We evaluated the changes in the length of hospital stay, ICU admission, mortality and total costs over time. From 1994 - 1999 to 2000 - 2009 there was a significant increase in ICU admission (4.8\% vs $6.3 \% ; p<0.001)$ and mortality $(17.2 \%$ vs $20.1 \% ; p<0.001)$. Length of hospital stay [10 days $(0-583)$ vs 9 days $(0-866) ; p<0.001]$ and total costs [€5884 (1358 - 265229$)$ vs $€ 5431$ euros (1358 - 393 318); $p<0.001$ ] significantly decreased over this period. However, from 2010 onwards, ICU admission and mortality remained stable $(6.3 \%$ vs $6.3 \% ; p=0.505$ and $20.1 \%$ vs $20.3 \% ; p=0.304$ ) although length of stay [ 9 days $(0-866)$ vs $9(0-455) ; p=0.001]$ and total costs [5.431 (1.358 - 393.318) vs 5,431 (1.358 - 207.295); $p<0.001]$ showed a slight increase.

Outcomes of patients according to weekday and weekend/holiday admission

The median length of hospital stay was 9.0 days (0 866). Three thousand one hundred seventy-one patients (5.9\%) required admission to the ICU, and 10440 patients (19.4\%) died during admission. The median admission costs amounted to $€ 5431$ (1358 - 393318 ). A full comparison of patients admitted during weekday and weekend/holidays is available in Table 2 .

Admission during a weekend or holiday was not associated with longer length of hospital stay - $9(0-866)$ vs $10(0-745) ; p=0.001$. These results persisted even after correcting for unexpectedly long admissions ( $>30$ days). As a result, total costs were lower in patients admitted during the weekend/holiday - €5884 (1358 - 338 552) vs €5431 (1358 - 393 318), for weekday and weekend/holiday respectively, $p=0.001$. This difference resulted from substantially higher expenses in patients over 75 years of age $(p=0.023)$.

The weekend effect was also not apparent in the need for intensive care management $(6.0 \%$ vs $5.7 \% ; p=0.109)$, development of organ failure $(10.0 \%$ vs $9.8 \% ; p=0.222)$ or sepsis $(5.5 \%$ vs $5.6 \% ; p=0.252)$, and mortality $(19.4 \%$ vs $19.3 \% ; p=0.374)$. This trend was seen in all age groups. $A$ detailed analysis is shown in Table 3 .

\section{Predictors of clinical outcomes according to weekday and weekend/holiday admission}

In logistic regression analysis, age (OR 1.029; 95\% $\mathrm{Cl} 1.027$ - 1.030), male gender (OR $1.242 ; 95 \% \mathrm{Cl} 1.187$ - 1.300; $p<0.001$ ), length of stay (OR 1.005; 95\% Cl $1.004-1.006 ; p<0.001$ ) and ICU admission (OR 6.284; $95 \% \mathrm{Cl} 5.814-6.791 ; p<0.001)$ but not weekend/holiday admission (OR $1.01795 \% \mathrm{Cl} 0.972-1.064, p=0.459$ ) were predictors of in-hospital mortality.

Table 2 - Comparison of patients admitted during a weekday and during weekend/holiday

\begin{tabular}{|c|c|c|c|}
\hline & $\begin{array}{l}\text { Weekday admissions } \\
\quad(n=30554)\end{array}$ & $\begin{array}{l}\text { Weekend and holiday admissions } \\
\qquad(n=23300)\end{array}$ & $p$ value $^{a}$ \\
\hline Age in years, median (IQR) & $78.9(19.9)$ & $79.7(19.6)$ & $<0.001$ \\
\hline$<50$ years, $\%$ & $35.7(10.6)$ & $35.8(10.4)$ & 0.859 \\
\hline $51-74$ years, $\%$ & $64.4(6.8)$ & $64.3(6.9)$ & 0.379 \\
\hline$\geq 75$ years, $\%$ & $89.9(8.6)$ & $90.2(8.5)$ & 0.006 \\
\hline Male gender, $\mathbf{n}(\%)$ & $16726(54.7)$ & $12673(54.4)$ & 0.422 \\
\hline$<50$ years, $\%$ & $1738(57.8)$ & 1239 (57.9) & 0.483 \\
\hline $51-74$ years, $\%$ & $3368(63.5)$ & 2552 (64.9) & 0.081 \\
\hline$\geq 75$ years, $\%$ & $11620(52.2)$ & $8882(51.6)$ & 0.089 \\
\hline Admission to ICU, $n$ (\%) & $1833(6.0)$ & $1338(5.7)$ & 0.109 \\
\hline$<50$ years, $\%$ & $226(7.0)$ & $169(7.4)$ & 0.325 \\
\hline $51-74$ years, $\%$ & $616(9.7)$ & $417(9.0)$ & 0.106 \\
\hline$\geq 75$ years, $\%$ & $956(4.6)$ & $736(4.6)$ & 0.373 \\
\hline Mortality, n (\%) & $5936(19.4)$ & $4500(19.3)$ & 0.374 \\
\hline$<50$ years, $\%$ & $222(6.9)$ & $157(6.8)$ & 0.499 \\
\hline $51-74$ years, $\%$ & 1034 (16.3) & $673(14.6)$ & 0.009 \\
\hline$\geq 75$ years, $\%$ & $4680(22.3)$ & $3670(22.4)$ & 0.432 \\
\hline LOS in days, median (IQR) & $14.0(18.6)$ & $13.5(18.2)$ & 0.001 \\
\hline$<50$ years, $\%$ & $14.5(23.2)$ & $14.3(25.6)$ & 0.754 \\
\hline $51-74$ years, $\%$ & $15.9(19.8)$ & $15.1(20.3)$ & 0.034 \\
\hline$\geq 75$ years, $\%$ & $13.3(17.4)$ & $12.9(16.2)$ & 0.011 \\
\hline Costs in euros, median (IQR) & $8141(9669)$ & $7685(8572)$ & 0.001 \\
\hline$<50$ years, $\%$ & $15565(22$ 442) & $13832(14864)$ & 0.425 \\
\hline $51-74$ years, $\%$ & $13846(12972)$ & $12236(14820)$ & 0.092 \\
\hline$\geq 75$ years, $\%$ & $7634(8738)$ & $7331(7826)$ & 0.023 \\
\hline
\end{tabular}

${ }^{a} p$ value determined by independent samples, Mann-Whitney $U$ test or two-tail chi-square tests.

IQR: Interquartile range; ICU: Intensive care unit; LOS: Length of hospital stay 
Table 3 - Comparison of organ failure in patients admitted during a weekday and during weekend/holiday

\begin{tabular}{|c|c|c|c|}
\hline & $\begin{array}{l}\text { Weekday admissions } \\
\quad(n=30554)\end{array}$ & $\begin{array}{l}\text { Weekend and holiday admissions } \\
\qquad(n=23300)\end{array}$ & $p$ value $^{a}$ \\
\hline Cardiovascular failure, $\mathrm{n}(\%)$ & $1073(3.5)$ & $746(3.2)$ & 0.026 \\
\hline$<50$ years, $\%$ & $70(2.2)$ & $40(1.7)$ & 0.153 \\
\hline $51-74$ years, $\%$ & $310(4.9)$ & $200(4.3)$ & 0.099 \\
\hline$\geq 75$ years, $\%$ & $693(3.3)$ & $506(3.1)$ & 0.126 \\
\hline Respiratory failure, n (\%) & $749(2.5)$ & $605(2.6)$ & 0.149 \\
\hline$<50$ years, $\%$ & $91(2.8)$ & $57(2.5)$ & 0.248 \\
\hline $51-74$ years, $\%$ & $180(2.8)$ & $153(3.3)$ & 0.081 \\
\hline$\geq 75$ years, $\%$ & $478(2.3)$ & $395(2.4)$ & 0.211 \\
\hline Renal failure, $n(\%)$ & $1042(3.4)$ & $789(3.4)$ & 0.450 \\
\hline$<50$ years, $\%$ & $33(1.0)$ & $32(1.4)$ & 0.129 \\
\hline $51-74$ years, $\%$ & $136(2.1)$ & $105(2.3)$ & 0.340 \\
\hline$\geq 75$ years, $\%$ & $873(4.2)$ & $652(4.0)$ & 0.195 \\
\hline Liver failure, $\mathrm{n}(\%)$ & $333(1.1)$ & $260(1.1)$ & 0.402 \\
\hline$<50$ years, $\%$ & $45(1.4)$ & $24(1.1)$ & 0.190 \\
\hline $51-74$ years, $\%$ & $122(1.9)$ & $106(2.3)$ & 0.097 \\
\hline$\geq 75$ years, $\%$ & $186(0.8)$ & $129(0.8)$ & 0.506 \\
\hline Any organ failure, $n(\%)$ & $3043(10.0)$ & $2273(9.8)$ & 0.222 \\
\hline$<50$ years, $\%$ & $147(7.1)$ & $229(6.4)$ & 0.169 \\
\hline $51-74$ years, $\%$ & $706(11.1)$ & $514(11.2)$ & 0.493 \\
\hline$\geq 75$ years, $\%$ & $2108(10.0)$ & $1612(9.8)$ & 0.254 \\
\hline Sepsis, n (\%) & $1675(5.5)$ & $1309(5.6)$ & 0.252 \\
\hline$<50$ years, $\%$ & $131(4.1)$ & $103(4.5)$ & 0.241 \\
\hline $51-74$ years, $\%$ & $464(7.3)$ & $336(7.3)$ & 0.499 \\
\hline$\geq 75$ years, $\%$ & $1080(5.1)$ & $870(5.3)$ & 0.252 \\
\hline
\end{tabular}

Organ failure was determined by a combination of ICD9 codes and resource utilization as previously described.

${ }^{a} p$ value determined by two-tail chi-square tests.

Similarly, younger age (OR $0.987 ; 95 \% \mathrm{Cl} 0.986-$ 0.989 ), male gender (OR 1.584; 95\% Cl 1.468 - 1.709; $p<$ 0.001 ), but not weekend/holiday admission (OR 1.036; $95 \%$ $\mathrm{Cl} 0.963-1.114 ; p=0.347$ ) were associated with the need for ICU admission.

The length of stay was directly associated with ICU admission (OR 1.12; 95\% Cl $1.11-1.14 ; p<0.001$ ), and negatively associated with increasing age (OR 0.99; $95 \%$ $\mathrm{Cl} 0.9996-0.9999 ; p=0.008)$, female gender $(0.97 ; 95 \%$ $\mathrm{Cl} 0.96-0.97 ; p<0.001)$, and weekend/holiday admission (OR 0.99; 95\% Cl $0.996-0.998 ; p=0.037$ ).

Finally, total costs were associated with ICU admission (OR 1.26; 95\% Cl 1.25 - 1.28; $p<0.001$ ), and negatively associated with increasing age (OR 0.9996; 95\% Cl 0.9995 - 0.9998; $p<0.001)$, female gender $(0.97 ; 95 \% \mathrm{Cl} 0.97$ $0.98 ; p<0.001$ ), and weekend/holiday admission (OR 0.99; $95 \% \mathrm{Cl} 0.986-0.996 ; p=0.001)$.

\section{Outcomes of patients according to the day of the week admission}

There were $8080,7597,7526,7366,7992,6599$, 6638 and 2078 patients admitted on Monday, Tuesday, Wednesday, Thursday, Friday, Saturday, Sunday, and public holidays, respectively.

The respective percentages of patients admitted to the ICU were 6.3\%, 6.1\%, 5.8\%, 5.8\%, 5.9\%, 5.2\%, 6.0\% and
$6.2 \%$ on Monday, Tuesday, Wednesday, Thursday, Friday, Saturday, Sunday, and public holidays, respectively. The correspondent in-hospital mortality was $20.0 \%, 18.7 \%$, $19.7 \%, 19.3 \%, 19.5 \%, 19.1 \%, 19.2 \%$ and $19.5 \%$ for Monday, Tuesday, Wednesday, Thursday, Friday, Saturday, Sunday, and public holidays. The ratio of total admissions, ICU transfers, and death according to the day of week is expressed in Fig. 1.

The median length of stay by day of admission was 9 (0 - 238), 9 (0 - 745), 9 (0 - 866), 8 (0 - 400), 10 (0 - 403), 9 (0 - 357), $9(0-458)$, and $9(0$ - 456), respectively for Monday, Tuesday, Wednesday, Thursday, Friday, Saturday, Sunday, and public holidays. Total costs by day of the week were 5431 (1358 - 131 148), 5431 (1358 - 207 748), 5431 (1358 - 393 318), 5431 (1358 - 182401$), 5884$ (1357 - 183 760), 5431 (1358 - 232 578), 5431 (1358 - 208 653), and 5431 (1358 - 338 552), respectively for Monday, Tuesday, Wednesday, Thursday, Friday, Saturday, Sunday, and public holidays.

\section{Predictors of clinical outcomes according to the day of the week admission}

Patients admitted on a Saturday were more likely to be admitted to the ICU (OR 1.168: 95\% CI 1.011 - 1.350; $p=0.034$ ), after adjusting for age and gender. Nevertheless, after adjusting for age, gender and ICU treatment, only 


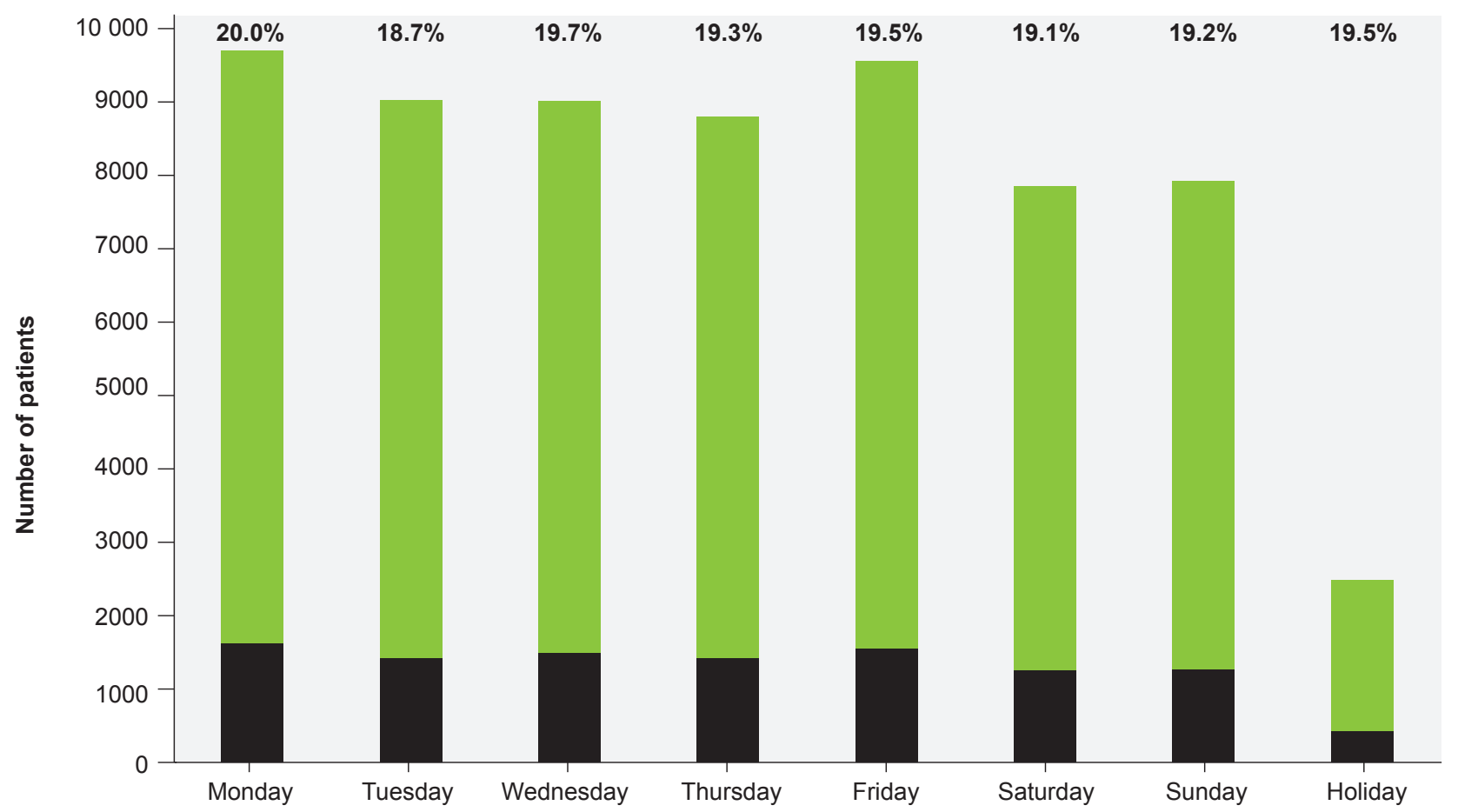

Day of admission

Figure 1 - The number of admitted patients with acute bacterial pneumonia and in-hospital mortality according with the day of admission

admission on a Monday (OR 0.916; $95 \% \mathrm{Cl} 0.844$ - 0.995; $p=0.038$ ) was significantly associated with a lower mortality (Fig. 2). Admission on any other day of the week, weekend or holiday was no associated with increased mortality. The results remained the same along all years included in the study.

\section{DISCUSSION}

Controversy over the existence of the weekend effect still exists. Several studies have pointed out that medical and surgical management of several conditions such as acute coronary syndrome, intracerebral hemorrhage and gastrointestinal bleeding might be substantial impaired during the weekend. ${ }^{2,16,17}$ A large observational study concluded that internal medicine patients who were admitted on weekends were more likely to undergo intubation (OR 1.27), mechanical ventilation (OR 1.25), cardiopulmonary resuscitation (OR 1.45), and transfer to an ICU (OR 1.16) during their hospitalization than those who were admitted on weekdays. ${ }^{5}$ One of the rationales for this effect is the lower numbers and experience of auxiliary, nursing and medical staff on duty during the weekend. ${ }^{2,12}$ It is certainly true that weekend shifts are more likely to be performed by junior doctors, often over-worked and subjected to increase levels of stress and tiredness. ${ }^{18}$ Lack of compliance with implemented guidelines may also account for the discrepancy in management over the weekend. ${ }^{9}$ Another explanation is that referral units might be less assessable to patients over the weekend. In countries like Portugal, primary health care resources are closed during national holidays and weekends. Consequently, care for these patients may be hampered during these periods.
This has been demonstrated by a recent observational study including 140 non-specialist acute hospital trusts in England. ${ }^{19}$ The authors found higher mortality rates in patients admitted to the hospital during weekends, especially in patients directly admitted from the community. Alarmingly, patients from the community were admitted in far smaller numbers at weekends. The authors concluded that extending services in hospitals and in the community at weekends may increase the number of emergency admissions and therefore lower mortality, but may not reduce the absolute number of deaths. However, a recent study did not detect a correlation between weekend staffing of hospital specialists and mortality risk for emergency admissions. ${ }^{20}$ While it appears that many medical and surgical conditions suffer from the weekend effect, there is still a paucity of data assessing the impact of weekend and holiday admissions on the outcomes of adult patients with respiratory infections. In 2014, Suissa et al published an interesting analysis of a large cohort (323 895 hospital admissions) of Quebec patients with chronic obstructive pulmonary disease and pneumonia. The authors confirmed that patients admitted on a Saturday or Sunday had an $8 \%$ higher risk of mortality compared with the Monday to Thursday period. Rather worryingly, this pattern showed no change over the 15-year window of observation. ${ }^{21}$ Uematsu $\mathrm{H}$ et al analyzed 23532 patients with severe pneumonia from 1044 acute care hospitals in Japan. Mortality rate of patients admitted during the weekend were significantly higher than of those admitted during weekdays $(23.7 \%$ vs $20.5 \% ; p<0.001)$, even after adjusting for severity and need for urgent care. Of interest, adherence to microbiologic tests, associated with lower in-hospital mortality, was 


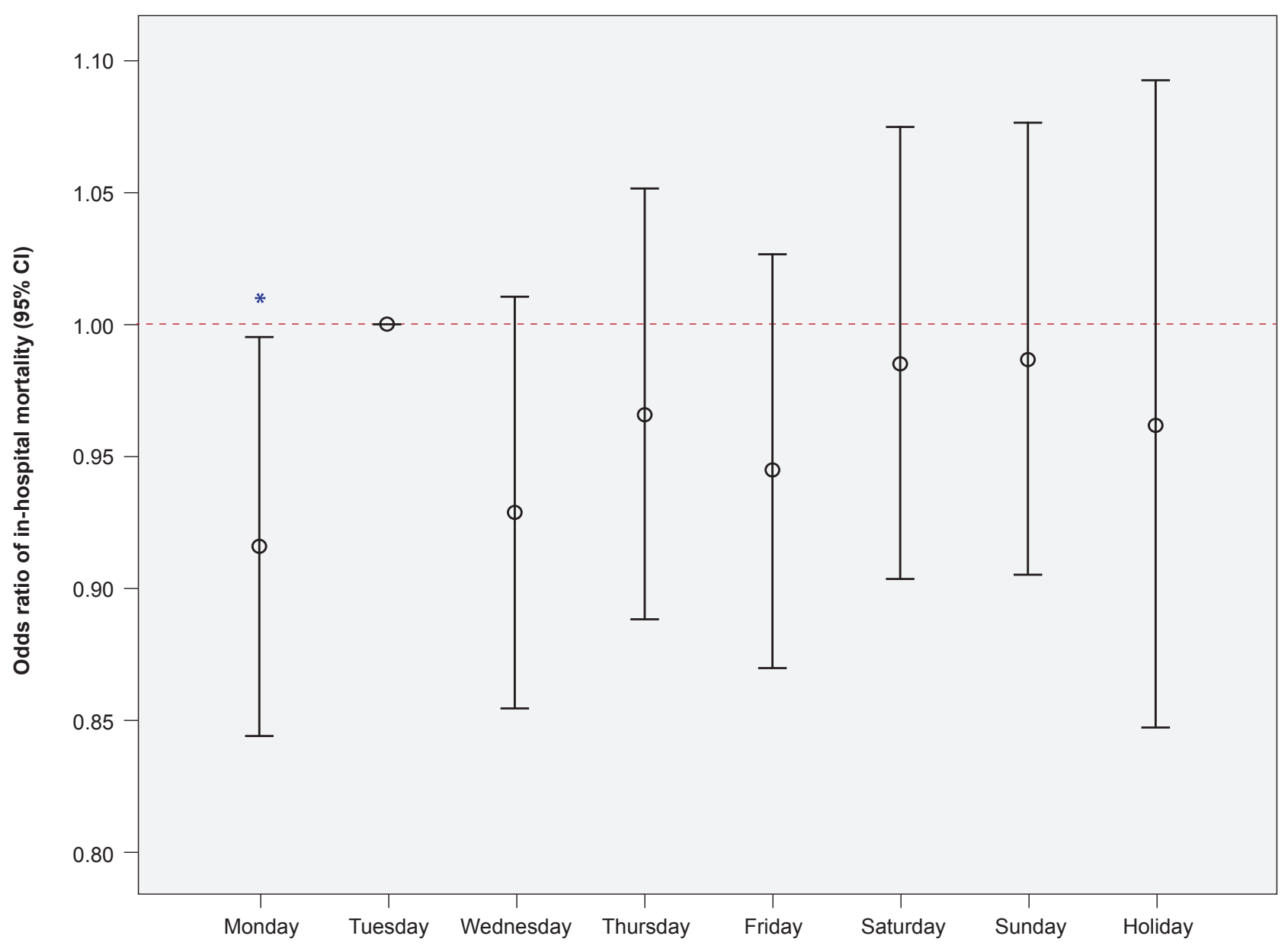

Day of admission

Figure 2-Odds ratio of in-hospital mortality of patients with acute bacterial pneumonia according with the day of admission with adjustment for age, gender and intensive care unit admission. Vertical bars indicate $95 \%$ confidence intervals.

significantly lower over the weekend admission group. ${ }^{9}$ Guann-Ming $\mathrm{C}$ et al evaluated admissions to general acute care hospitals throughout Taiwan and found a 3\% higher odd of 30-day death in patients hospitalized during the weekend. ${ }^{10}$ Another study showed an association between mortality and weekend admission nurse staffing levels and hospital occupancy. ${ }^{12}$ Like in our study, other authors have failed to show a significance of the weekend effect in patients with pneumonia. In a cross-sectional analysis of 95704 emergency department admissions in the United States with pneumonia, weekend admissions were not associated with increased mortality. ${ }^{11}$ Schmulewitz $L$ et al assessed 3244 hospital admissions to the Royal Infirmary of Edinburgh including patients with pneumonia, chronic obstructive pulmonary disease, cerebrovascular accidents, pulmonary embolism, collapse and upper gastrointestinal bleed. ${ }^{13}$ The authors concluded that the mortality rate was significantly lower for patients admitted with pneumonia during the weekend (OR $0.50 ; p=0.015$ ).

In our study, we assessed admissions with bacterial pneumonia over a 25-year period in a major tertiary hospital in Portugal. As in the latter studies, weekend and holiday admissions were not associated with any of the outcomes studies including costs, length of stay, ICU admission, sepsis, organ failure and mortality. Unexpectedly, weekend and holiday admissions were associated with shorter lengths of hospital stay, a finding that was not dependent on admissions due to potential social reasons.

It is certainly difficult to interpret the mixed results from different studies. One possible explanation may arise from the differences in the organization of the health-care system across different countries. For example, the Portuguese health care system relies heavily on hospital-centered health care management, meaning that patients will often seek hospital evaluation instead of primary care physicians. While it is certainly true that the lack of recourses during the weekend in community-based health care systems may contribute to the weekend effect, ${ }^{20}$ in countries like Portugal this may actually result in patients with more severe disease seeking hospital care earlier. This may partly explain the lower length of hospital stay of patients admitted during the weekend in our series. On the other hand, the mandatory presence of internal medicine specialists in our emergency department may partly justify the absence of a negative impact of weekend and holiday admissions on mortality, due to the availability of adequate means and knowledge for the early management of pneumonia.

Our study has many strengths. Assessing a single center over a wide period avoided potential confounders associated with hospital policies and emergency 
management over time. Furthermore, our study is one of the first assessing the effect of weekend and holiday admission on the development of sepsis and organ failure.

Nevertheless, several biases might have influenced our results. Although we considered several widely-accepted surrogates of severity such as the need for ICU treatment, development of sepsis and organ failure, we did not stratify patients according with a severity score such as the CURB-65 or the pneumonia severity index. ${ }^{10,11}$ While most studies have used these scores as markers of severity, grouping patients according with the need for intensive care management and development of sepsis and organ failure may better assess mortality in critical care patients. ${ }^{22}$ It is true that organ failure and sepsis were defined according with ICD-9 diagnosis and procedure codes rather than by laboratory data or physician documentation. Nevertheless, this approach has been used in other studies with similar methodology. ${ }^{14,15}$ Furthermore, as the same method was used for determining organ failure and sepsis in all patients, this limitation should have little impact on comparisons between weekend and weekday admissions.

\section{REFERENCES}

1. Keogh B. Review into the quality of care and treatment provided by 14 hospital trusts in England: overview report [Internet]. 2013 [Access 2016 Jun 27]. Available from: http://www.nhs.uk/nhsengland/bruce-keoghreview/documents/outcomes/keogh-review-final-report.pdf

2. Khoshchehreh M, Groves E, Tehrani D, Amin A, Patel P, Malik S Changes in mortality on weekend versus weekday admissions for acute coronary syndrome in the United States over the past decade. Int J Cardiol. 2016;210:164-72.

3. Deshmukh H, Hinkley M, Dulhanty L, Patel H, Galea J. Effect of weekend admission on in-hospital mortality and functional outcomes for patients with acute subarachnoid haemorrhage (SAH). Acta Neurochir. 2016;158:829-35.

4. Hamada T, Yasunaga $H$, Nakai $Y$, Isayama $H$, Matsui $H$, Fushimi $K$, et al. No weekend effect on outcomes of severe acute pancreatitis in Japan: data from the diagnosis procedure combination database. J Gastroenterol. 2016;51:1063-72.

5. Huang C, Huang Y, Hsu N, Chen J, Yu C. Effect of weekend admissions on the treatment process and outcomes of internal medicine patients. Medicine. 2016;95:e2643.

6. Torres A, Ewig S, Lode H, Carlet J. Defining, treating and preventing hospital acquired pneumonia: european perspective. Intensive Care Med. 2008;35:9-29.

7. Kollef K, Schramm G, Wills A, Reichley R, Micek S, Kollef M. Predictors of 30-day mortality and hospital costs in patients with ventilatorassociated pneumonia attributed to potentially antibiotic-resistant gramnegative bacteria. Chest. 2008;134:281-7.

8. Restrepo M, Anzueto A. Severe community-acquired pneumonia. Infect Dis Clin North Am. 2009;23:503-20.

9. Uematsu H, Kunisawa S, Yamashita K, Fushimi K, Imanaka Y. Impact of weekend admission on in-hospital mortality in severe communityacquired pneumonia patients in Japan. Respirology. 2016;21:905-10.

10. Chang G, Tung Y. Factors associated with pneumonia outcomes: a nationwide population-based study over the 1997-2008 period. J Gen Intern Med. 2011;27:527-33.

11. Quattromani E, Powell E, Khare R, Cheema N, Sauser K, Periyanayagam $U$, et al. Hospital-reported data on the pneumonia quality measure "Time to First Antibiotic Dose" are not associated with inpatient mortality: results of a nationwide cross-sectional analysis. Acad Emerg Med.

\section{CONCLUSION}

In conclusion, our data strongly suggests that the weekend effect might not be present in patients with acute bacterial pneumonia admitted to tertiary cares in Portugal.

\section{PROTECTION OF HUMANS AND ANIMALS}

The authors declare that the procedures were followed according to the regulations established by the Clinical Research and Ethics Committee and to the Helsinki Declaration of the World Medical Association.

\section{DATA CONFIDENTIALITY}

The authors declare having followed the protocols in use at their working center regarding patients' data publication.

\section{CONFLICTS OF INTEREST}

The authors declare that there are no conflicts of interest.

\section{FUNDING SOURCES}

No subsidies or grants contributed to this work.

2011;18:496-503.

12. Schilling P, Campbell D, Englesbe M, Davis M. A comparison of inhospital mortality risk conferred by high hospital occupancy, differences in nurse staffing levels, weekend admission, and seasonal influenza. Med Care. 2010;48:224-32.

13. Schmulewitz L, Proudfoot A, Bell D. The impact of weekends on outcome for emergency patients. Clin Med. 2005;5:621-5.

14. Goodman E, Reilly A, Fisher B, Fitzgerald J, Li Y, Seif A, et al. Association of weekend admission with hospital length of stay, time to chemotherapy, and risk for respiratory failure in pediatric patients with newly diagnosed leukemia at freestanding US children's hospitals. JAMA Pediatr. 2014;168:925-31.

15. Maude S, Fitzgerald J, Fisher B, Li Y, Huang Y, Torp K, et al. Outcome of pediatric acute myeloid leukemia patients receiving intensive care in the United States. Pediatr Crit Care Med. 2014;15:112-20.

16. Patel A, Mahajan A, Benjo A, Pathak A, Kar J, Jani V, et al. A nationwide analysis of outcomes of weekend admissions for intracerebral hemorrhage shows disparities based on hospital teaching status. The Neurohospitalist. 2015;6:51-8.

17. Ahmed A. Upper gastrointestinal bleeding in Scotland 2000-2010: improved outcomes but a significant weekend effect. World J Gastroenterol. 2015;21:10890-7.

18. Davenport M, Ellis J, Khalatbari S, Myles J, Klein K. Effect of work hours, caseload, shift type, and experience on resident call performance. Acad Radiol. 2010;17:921-7.

19. Aldridge C, Bion J, Boyal A, Chen Y, Clancy M, Evans T, et al. Weekend specialist intensity and admission mortality in acute hospital trusts in England: a cross-sectional study. Lancet. 2016;388:178-86.

20. Meacock R, Anselmi L, Kristensen S, Doran T, Sutton M. Higher mortality rates amongst emergency patients admitted to hospital at weekends reflect a lower probability of admission. J Health Serv Res Policy. 2016. [Epub ahead of print].

21. Suissa S, Dell'Aniello S, Suissa D, Ernst P. Friday and weekend hospital stays: effects on mortality. Eur Respir J. 2014;44:627-33.

22. Vincent J, de Mendonca A, Cantraine F, Moreno R, Takala J, Suter P, et al. Use of the SOFA score to assess the incidence of organ dysfunction/ failure in intensive care units. Crit Care Med. 1998;26:1793-800. 